\title{
Gambaran Psikososial pada Pasien Multidrug Resistant Tuberculosis dengan Gangguan Dengar Sensorineural di Rumah Sakit Hasan Sadikin Bandung
}

\author{
Hayati Syarifah $^{1}$, Indah Amelia², Ratna Anggraeni ${ }^{3}$ \\ ${ }^{1}$ Fakultas Kedokteran Universitas Padjadjaran \\ ${ }^{2}$ Departemen Ilmu Kesehatan Masyarakat, Fakultas Kedokteran, Universitas Padjadjaran \\ ${ }^{3}$ Departemen Ilmu Kesehatan Telinga Hidung Tenggorokan-Bedah Kepala Leher, Fakultas Kedokteran, \\ Universitas Padjadjaran/Rumah Sakit Umum Dr. Hasan Sadikin, Bandung, Indonesia
}

\begin{abstract}
Abstrak
Pasien Multidrug Resistant Tuberculosis (MDR TB) diterapi dengan obat anti tuberkulosis lini kedua, seperti kanamisin. Kanamisin bersifat ototoksik, yang menyebabkan pasien berisiko mengalami gangguan dengar sensorineural (SNHL). Gangguan dengar ini dapat memberikan efek terhadap psikososisal seseorang yang menyebabkan keterbatasan dalam mejalankan kehidupan sehari-hari (handicap). Penelitian ini bertujuan untuk mengetahui gambaran psikososial pada pasien MDR TB dengan gangguan dengar sensorineural di Rumah Sakit Hasan Sadikin Bandung. Metode penelitian ini berupa deskriptif kuantitatif yang dilakukan dari September - Desember 2016. Penelitian dilakukan pada pasien yang berobat di Poli MDR TB RSHS yang memenuhi kriteria inklusi dan eksklusi. Subjek penelitian di wawancara melalui telepon dengan menggunakan kuesioner Hearing Handicap Inventory for Adults (HHIA). Jumlah subjek pada penelitian ini sebanyak 26 responden. Hasil penelitian ini menunjukkan sebagian besar skor HHIA terhitung rendah, meskipun dengan rentang nilai yang cukup besar (0-48). Sebagian besar responden memiliki SNHL derajat ringan di telinga kirikanan (SNHL ringan-ringan). Responden dengan SNHL ringan-ringan atau ringan-sedang tidak merasakan handicap. Responden dengan SNHL derajat ringan-berat dan sedang-sedang mengalami mild-moderate handicap. Responden dengan SNHL derajat berat-berat mengalami significant handicap. Kesimpulannya, keadaan psikososial pada pasien MDR TB dengan SNHL tergantung dari derajat SNHL yang diderita.
\end{abstract}

Kata Kunci : handicap, MDR TB, psikososial, SNHL

\section{Psychosocial States of Multidrug Resistant Patients with Sensorineural Hearing Loss in Hasan Sadikin General Hospital}

\author{
Abstract
}

Patients with Multidrug Resistant Tuberculosis (MDR TB) is treated by second line antituberculosis drugs such as kanamycin. Kanamycin has an ototoxic effect which increased risk of developing sensorineural hearing loss (SNHL). Hearing loss might impact psychosocial well-being and limitation in daily activity (handicap). The aim of this study is to discover psychosocial states of MDR TB patients with SNHL in Hasan Sadikin General Hospital (RSHS). A quantitative descriptive study was conducted from September-December 2016. Patient of MDR TB clinic in RSHS which fulfilled the inclusion and exclusion criteria were enrolled in the study. Respondent were interviewed by phone following the questions enlisted in Hearing Handicap Inventory for Adults (HHIA) questionnaire. A total of 26 respondent were recruited in this study. Most of HHIA scores were considered low, nevertheless the range of score was quite high (0-48). Most of the respondents had mild SNHL in left-right ear (mild-mild SNHL). Respondents with mild-mild SNHL and mild-moderate SNHL did not have handicap, while respondents with mild-severe SNHL and moderate-moderate SNHL have mild-moderate handicap. Respondents with severe-severe SNHL had significant handicap. It can be concluded that psychosocial states of MDR TB patients ware relative to their degree of SNHL.

Keywords : handicap, MDR TB, psychosocial, SNHL

Korespondensi:

Hayati Syarifah

Fakultas Kedokteran Universitas Padjadjaran

Jl. Raya Bandung-Sumedang KM 21 Jatinangor, Sumedang

Mobile : 0896414875907

Email : hayatisyarifah2711@gmail.com 


\section{Pendahuluan}

Psikososial adalah hubungan yang dinamis antara psikologis dan sosial yang saling mempengaruhi. Gangguan psikososial merupakan setiap perubahan dalam kehidupan individu yang bersifat sosial yang mempunyai pengaruh terjadinya gangguan psikologis/ kejiwaan atau sebaliknya masalah psikologis yang dapat berdampak pada lingkungan sosial. Apabila keadaan psikososial tersebut terganggu seseorang dapat mengalami keterbatasan dalam menjalankan kehidupan sehari-hari atau biasa disebut dengan handicap. Salah satu hal yang dapat mengakibatkan terganggunya keadaan psikososial seseorang adalah akibat terganggunya pendengaran. .,2,3 $^{1}$

Seseorang dengan gangguan dengar akan mengalamikesulitan dalammengenalkata, kalimat atau mendengarkan pembicaraan. Hal tersebut dapat mengganggu komunikasi. Gangguan dengar dapat memberikan efek ke aspek sosial penderitanya seperti penurunan dalam membuka diri ke masyarakat, meningkatnya masalah relasi dengan teman dan keluarga. tersebut dapat memiliki dampak yang signifikan pada kehidupan sehari-hari, mereka akan mengalami perasaan kesepian, terisolasi dan frustrasi. Gangguan dengar juga dapat memberikan efek ke aspek psikologis atau emosi seperti mengakibatkan depresi, mudah marah, perasaan rendah diri., ${ }^{1,2,3}$ Salah satu penyebab terganggunya pendengaran adalah akibat obat yang bersifat ototoksik seperti golongan aminoglikosida yang biasa digunakan pada pasien Multidrug Resistant Tuberculosis (MDR TB). ${ }^{4}$

Multidrug Resistant Tuberculosis (MDR TB) merupakan penyakit tuberkulosis yang resisten minimal terhadap isoniazid and rifampisin dengan atau tanpa disertai resisten terhadap obat antituberkulosis (OAT) lainnya. ${ }^{5}$ Indonesia merupakan salah satu negara dengan kasus MDR TB terbanyak di dunia, diperkirakan terdapat 6.800 kasus baru setiap tahunnya. ${ }^{6}$ Berbeda dengan pasien TB yang tidak resisten, pasien MDR TB diobati dengan OAT lini kedua. Obat lini kedua ini tidak seefektif OAT lini pertama dan memiliki lebih banyak efek samping. Salah satu obat yang dikonsumsi oleh pasien MDR TB adalah Aminoglikosida seperti kanamisin yang memiliki sifat ototoksik. ${ }^{5}$

Kanamisin dapat merusak sel-sel rambut luar yang terdapat di koklea sehingga pasien MDR TB memiliki risiko berkembangnya gangguan dengar sensorineural (SNHL). Obat tersebut pada awalnya akan memengaruhi daerah basal koklea. Selanjutnya paparan tersebut dapat menyebabkan penyebaran kerusakan ke arah apeks. Hal itu menyebabkan terjadinya suatu gangguan dengar sensorineural yang bertahap, pada awalnya hanya memengaruhi frekuensi tinggi, kemudian meluas ke frekuensi yang lebih rendah. Gangguan dengar frekuensi $10.000 \mathrm{~Hz}$ mulai terjadi pada hari ke19-21, kemudian mengenai frekuensi $8.000 \mathrm{~Hz}$ pada hari ke-25-27.4,7

Data dari penelitian di poliklinik MDR TB Ilmu Penyakit Dalam Rumah Sakit Hasan Sadikin Bandung pada tahun 2013 didapatkan 72 pasien MDR TB dengan hasil audiometri normal sebelum memulai terapi TB MDR. Selama mendapat terapi MDR TB yaitu pengobatan dengan kanamisin didapatkan 15 pasien $(20,8 \%)$ mengeluhkan penurunan pendengaran yang dibuktikan dengan hasil pemeriksaan audiometri. ${ }^{8}$ Pasien dengan gangguan pendengaran tersebut belum pernah di ketahui gambaran psikososialnya. Atas dasar pertimbangan tersebut penelitian ini dilakukan dengan tujuan untuk mengetahui gambaran psikososial pada pasien MDR TB dengan gangguan dengar sensorineural di Rumah Sakit Hasan Sadikin Bandung.

\section{Metode}

Metode penelitian yang digunakan dalam penelitian ini adalah metode deskriptif kuantitatif cross sectional. Penelitian dilakukan dari bulan September sampai Desember 2016 di poliklinik MDR TB Ilmu Penyakit Dalam RS Hasan Sadikin Bandung. Populasi pada penelitian ini adalah pasien MDR TB yang berobat di RS Hasan Sadikin Bandung pada tahun 2016.

Kriteria inklusi pada penelitian ini adalah pasien MDR TB yang mendapatkan pengobatan kanamisin lebih dari satu bulan dengan usia antara 18-60 tahun yang memiliki gangguan dengar sensorineural yang dibuktikan melalui hasil pemeriksaan audiometri. Sedangkan kriteria eksklusinya adalah pasien yang memiliki riwayat gangguan dengar sebelum pengobatan MDR TB, sudah menggunakan alat bantu dengar, mempunyai riwayat terpapar suara bising, mempunyai riwayat gangguan psikososial sebelumnya dan tidak terdapat nomor telepon yang tercatat dalam rekam medis. Sampel pada penelitian ini diambil dengan menggunakan metode total sampling yaitu setiap pasien MDR TB yang memenuhi kriteria inklusi dan eksklusi akan menjadi subjek penelitian. Pengambilan data dilakukan setelah mendapatkan persetujuan dari Komisi Etik Penelitian Kesehatan (No: 549/UN6. C1.3.2/KEPK/PN/2016) dan surat izin penelitian (Nomor: LB.02.01/C02/9549/VII/2016). Data awal diambil melalui rekam medis di poli MDR TB RSHS. Data kemudian di seleksi berdasarkan kriteria inklusi dan eksklusi yang 
sudah ditentukan. Subjek penelitian kemudian di wawancara melalui telepon dengan menggunakan kuesioner Hearing Handicap Inventory for Adults (HHIA). Responden dengan SNHL derajat ringan wawancara dilakukan melalui telepon secara langsung kepada responden, sedangkan responden yang memiliki SNHL derajat sedang dan berat wawancara dilakukan dengan dibantu oleh kerabat atau tetangga responden.

Terdapat beberapa kuesioner yang dapat menilai keadaan psikososial pada pasien gangguan dengar seperti Hearing Handicap Inventory for Adults (HHIA), Hearing Handicap Inventory for the Elderly (HHIE), Hearing Handicap and Disability Inventory (HHDI), Hearing Handicap Questionnaire (HHQ). Pada penelitian ini menggunakan kuesioner HHIA dikarenakan kuesioner tersebut paling sering digunakan dalam penelitian dan meniliki internal consistency yang baik dan test-retest reability yang tinggi. Kuesioner HHIA yang terdiri atas 25 pertanyaan terbagi atas 2 aspek yaitu emosi (13 pertanyaan) dan sosial (12 pertanyaan). Setiap pertanyaan bernilai 4 untuk jawaban "ya", nilai 2 untuk jawaban "kadang-kadang" dan nilai 0 untuk jawaban "tidak". 1,2,3

Kuesioner ini diadaptasi ke bahasa Indonesia dan sudah melalui uji validitas dan reabilitas. Cronbach's alpha kuesioner HHIA adalah 0.925, sedangkan cronbach's alpha aspek sosial dan emosi adalah 0.833 dan 0.889 . Hal tersebut menunjukkan kuesioner HHIA bersifat reliable. Spearman's correlation coefficients antara skor total HHIA dan aspek sosial and emosi adalah 0.937 dan 0.968 dan keduanya signifikan secara statistik $(\mathrm{p}<0.001)$. Setelah data terkumpul, selanjutnya dilakukan proses pengolahan data dan disajikan dalam bentuk tabel untuk menggambarkan nilai HHIA pada subjek penelitian. Selain itu, hasil data juga akan dikategorikan dan ditarik kesimpulannya. Data tersebut dapat dikategorikan dengan cara total skor keseluruhan dibagi 100. Jika hasil skor HHIA 0-16\% dikategorikan sebagai no handicap, $18-42 \%$ dikategorikan sebagai mild moderate handicap, dan lebih dari 44\% maka dikategorikan mengalami significant handicap..$^{1,2,3}$

\section{Hasil}

Berdasarkan catatan rekam medis, terdapat 154 pasien MDR TB yang melakukan pengobatan di RSHS Bandung tahun 2016, namun yang menggunakan kanamisin dan mengalami gangguan pendengaran sensorineural sebanyak 44 orang. Sebanyak 10 orang di eksklusi, dikarenakan 5 orang berusia lebih dari 60 tahun, dan 5 orang tidak terdapat nomor telepon dalam rekam medisnya. Dari 34 pasien yang masuk ke dalam kriteria inklusi dan eksklusi, 8 orang tidak dapat dihubungi, sehingga hanya sebanyak 26 orang yang masuk ke dalam subjek penelitian.

Subjek berjenis kelamin laki-laki lebih banyak dibandingkan dengan subjek berjenis kelamin perempuan. Usia responden mulai dari 22 tahun hingga 57 tahun. Kelompok usia terbanyak pada kelompok usia 26-35 tahun. Derajat gangguan dengar sensorineural pada pasien MDR TB paling banyak adalah derajat ringan di kedua telinga.

Tabel 1 Proporsi responden berdasarkan jenis kelamin, usia, dan derajat gangguan dengar sensorineural.

\begin{tabular}{ccc}
\hline No & Variabel & Frekuensi \\
\hline 1 & Jenis Kelamin & \\
& Laki-laki & 18 \\
& Perempuan & 8 \\
2 & Usia & \\
& $18-25$ & 2 \\
& $26-35$ & 11 \\
& $36-45$ & 5 \\
& $46-55$ & 7 \\
& $55-60$ & 1 \\
3 & Derajat SNHL & \\
& Ringan - Ringan & 17 \\
& Ringan - Sedang & 4 \\
& Ringan - Berat & 2 \\
& Sedang-Sedang & 2 \\
& Berat - Berat & 1 \\
\hline
\end{tabular}

Derajat SNHL (sensorineural hearing loss):

Ringan - Ringan : derajat ringan di kedua telinga

Ringan - Sedang : derajat ringan di salah satu telinga dan derajat sedang di telinga lainnya

Ringan - Berat : derajat ringan di salah satu telinga dan derajat berat di telinga lainnya

Sedang - Sedang : derajat sedang di kedua telinga

Berat - Berat : derajat berat di kedua telinga

Hasil penelitian memiliki distribusi data yang tidak normal sehingga peneliti memilih median sebagai ukuran pemusatan dan minimummaksimum sebagai ukuran penyebaran. Median total skor HHIA dari semua responden terhitung rendah yaitu 2 , dengan rentang nilai yang cukup besar yaitu mulai dari skor 0 hingga 48 . Skor emosi lebih besar dibandingkan dengan skor sosial. Handicap dari aspek sosial terbanyak yang dialami oleh responden kesulitan ketika berkunjung ke teman, sanak keluarga, atau 
tetangga dan kesulitan dalam mendengar televisi, radio. Handicap dari aspek emosi terbanyak yang dialami oleh responden adalah gangguan dengar menyebabkan responden merasa kesulitan, gelisah/ gugup dan merasa tidak nyaman ketika berbicara dengan teman.

Tabel 2 Skor total, emosi dan sosial kuesioner HHIA pada pasien MDR TB dengan gangguan dengar sensorineural

\begin{tabular}{lccc}
\hline \multicolumn{1}{c}{$\begin{array}{c}\text { Skor } \\
\text { HHIA }\end{array}$} & Median & Minimum & Maksimum \\
\hline Total & 2 & 0 & 48 \\
Emosi & 2 & 0 & 32 \\
Sosial & 0 & 0 & 16 \\
Keterangan: \\
$\begin{array}{l}\text { HHIA = kuesioner Hearing } \\
\text { Adults }\end{array}$
\end{tabular}

Tabel 3 Gambaran psikososial berdasarkan derajat gangguan dengar sensorineural

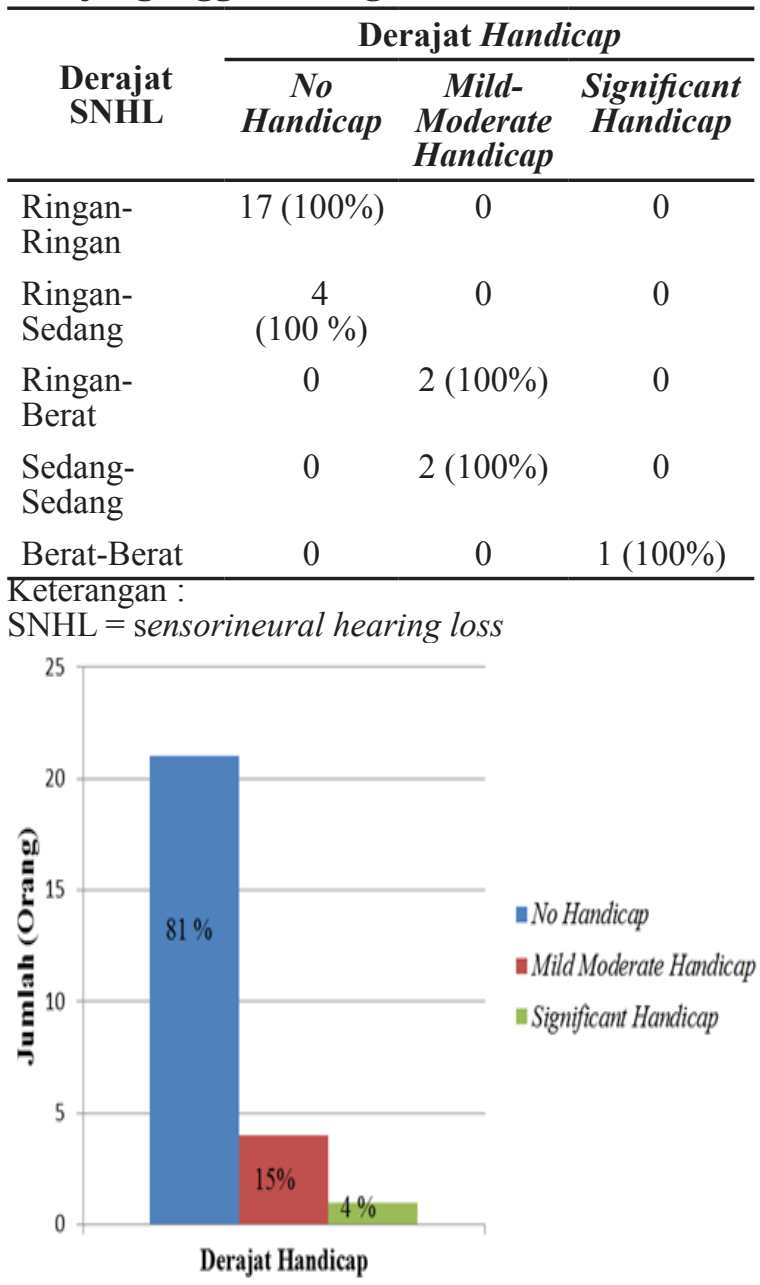

Gambar 1 Derajat handicap pada pasien MDR TB dengan gangguan dengar sensorineural
Bila skor HHIA tersebut dikategorikan, sebagian besar responden tidak merasakan handicap. Hanya $19 \%$ responden yang merasakan handicap, baik derajat mild-moderate atau significant.

Pasien MDR TB dengan gangguan dengar sensorineural derajat ringan-ringan dan ringansedang, seluruhnya tidak mengalami handicap. Pasien MDR TB dengan gangguan dengar sensorineural derajat ringan-berat dan sedangsedang, seluruhnya mengalami mild-moderate handicap. Pasien MDR TB dengan gangguan dengar sensorineural derajat berat-berat mengalami significant handicap.

\section{Pembahasan}

Pada hasil penelitian ini didapatkan pasien MDR TB yang mengalami gangguan dengar sensorineural di RS Hasan Sadikin sebagian besar adalah pria. Keadaan ini sesuai dengan penelitian yang sudah dilakukan di RSHS sebelumnya ${ }^{4,8}$ Namun hasil ini berbeda dengan penelitian yang dilakukan oleh Reviono dkk. ${ }^{9}$ Perbedaan ini kemungkinan disebabkan oleh jumlah subjek penelitian yang diteliti tidak sama dan tidak ada hubungan antara insidensi pasien MDR TB yang memiliki SNHL dengan jenis kelamin. Berdasarkan usia, hasil penelitian menunjukkan pasien paling banyak terdapat pada kelompok usia 26-35. Hasil ini sesuai dengan penelitian lainnya., ${ }^{4,8}$ Sebagian besar subjek penelitian merupakan usia produktif sehingga aktivitasnya yang lebih tinggi dan kontak dengan lingkungan juga lebih tinggi Derajat gangguan pendengaran bervariasi mulai dari ringan hingga berat. Derajat gangguan dengar yang diderita oleh pasien MDR TB paling banyak adalah derajat ringan. Hal ini sesuai dengan penelitian yang dilakukan oleh Yulianti $\mathrm{dkk}^{8}{ }^{8}$ Salah satu kemungkinan penyebab gangguan dengar pada pasien MDR TB sebagian besar hanya berderajat ringan dikarenakan peningkatan ambang dengar hanya terjadi di frekuensi tertentu, terutama pada frekuensi tinggi. Hal ini disebabkan toksisitas koklea yang pada awalnya hanya memengaruhi daerah basal koklea, kemudian meluas ke arah apeks. Sehingga pada awalnya hanya memengaruhi frekuensi tinggi. ${ }^{4,7,10,11}$ Sedangkan untuk mengklasifikasikan derajat pendengaran dinilai dengan cara menghitung rata- rata ambang dengar dalam $\mathrm{dB}$ (desibel) pada frekuensi 500 hingga $4000 \mathrm{~Hz}$.

Skor HHIA pada penelitian ini terhitung rendah, dengan median 2. Belum terdapat penelitian sebelumnya yang menilai skor HHIA pada pasien MDR TB dengan gangguan dengar sensorineural. Penelitian yang sudah pernah 
dilakukan hanya menilai HHIA pada pasien gangguan dengar secara umum, tidak dikarenakan penyebab khusus misalnya karena pengobatan MDR TB. Penelitian ini menunjukkan hasil skor HHIA yang lebih rendah jika dibandingkan dengan penelitian pada pasien gangguan dengar secara umum. ${ }^{1,2,12}$ Perbedaan ini kemungkinan dikarenakan oleh perbedaan populasi dan derajat gangguan pendengaran pada populasi yang diteliti. Namun terdapat persamaan dari penelitian sebelumnya yaitu skor emosi lebih besar dibandingkan skor sosial. ${ }^{1,2,12}$

Handicap dari aspek sosial terbanyak yang dialami oleh responden kesulitan ketika berkunjung ke teman, sanak keluarga, atau tetangga dan kesulitan dalam mendengar televisi, radio. Handicap dari aspek emosi terbanyak yang dialami oleh responden adalah gangguan dengar menyebabkan responden merasa kesulitan, gelisah/ gugup dan merasa tidak nyaman ketika berbicara dengan teman. Tidak ada penelitian dengan responden gangguan dengan instrumen HHIA yang menjabarkan poin handicap yang terbanyak dirasakan oleh responden.

Bila skor HHIA semua responden tersebut dikategorikan, sebagian besar responden tidak merasakan handicap. Hal tersebut dikarenakan sebagian besar subjek penelitian memiliki derajat gangguan dengar ringan. Responden dengan gangguan dengar sensorineural derajat ringan - ringan dan ringan - sedang seluruhnya tidak mengalami handicap. Responden dengan gangguan dengar sensorineural derajat ringan berat dan sedang - sedang seluruhnya mengalami mild - moderate handicap. Responden dengan gangguan dengar sensorineural derajat berat di kedua telinga mengalami significant handicap.

Tingkat handicap yang berbeda dikarenakan pada gangguan dengar ringan pasien tidak akan mengalami keluhan yang berarti, sedangkan pada gangguan dengar yang lebih berat pasien akan mulai merasakan keluhan di saat pasien sudah mengalami kesulitan dalam berkomunikasi. ${ }^{13}$ Pasien gangguan dengar dengan derajat yang lebih berat lebih memungkinkan seseorang mengalami penurunan kualitas hidupnya dikarenakan adanya perasaan terisolasi, produktivitas yang menurun dan berkurangnya aktivitas sosial dan rasa percaya diri yang rendah. ${ }^{14}$

Dari penelitian ini dapat disimpulkan pasien MDR TB dengan gangguan dengar sensorineural ringan tidak mengalami gangguan psikososial (no handicap). Pasien MDR TB mulai mengalami gangguan psikososial (mild-moderate handicap) apabila SNHL derajat ringan disalah satu sisi telinga dan berat di telinga lainnya atau derajat sedang di kedua sisi telinga. Pasien MDR TB dengan gangguan dengar sensorineural berat pada kedua telinga mengalami gangguan psikososial berat yang dapat menghambat kehidupan sehariharinya (significant handicap).

Keterbatasan penelitian ini adalah jumlah sampel yang sedikit. Selain itu penelitian dilakukan melalui telepon sehingga lebih memungkinkan terjadinya information bias. Pemilihan metode penelitian melalui telepon ini dikarenakan adanya keterbatasan waktu penelitian dan keterbatasan kemampuan pasien untuk datang ke RSHS dikarenakan jarak rumah pasien yang cukup jauh. Penelitian ini diharapkan dapat menjadi dasar untuk penelitian serupa dengan sampel penelitian yang lebih besar dan melakukan penelitian dengan interview secara langsung.

Hasil penelitian ini juga diharapkan dapat bermanfaat sebagai acuan bagi petugas kesehatan dalam penanganan pasien MDR TB yang mengalami gangguan dengar terutama dengan derajat sedang maupun berat sehingga pengobatan tidak sebatas dalam pengobatan untuk penyakitnya saja tetapi dilakukan juga konseling menangani psikososial pasien tersebut. Skor emosional yang lebih tinggi dapat menjadi acuan untuk menekankan konseling dari segi emosi pasien. Namun aspek sosial juga harus tetap diperhatikan, dikarenakan emosi maupun sosial saling memengaruhi satu sama lain.

\section{Daftar Pustaka}

1. Monzani D, Galeazzi GM, Genovese E, Marrara A, Martini A. Psychological profile and social behaviour of working adults with mild or moderate hearing loss. Acta Otorhinolaryngologica Italica. 2008;28:616.

2. Monzani D, Genovese E, Palma S, Rovatti $\mathrm{V}$, Borgonzoni M, Martini A. Measuring the psychosocial consequences of hearing loss in a working adult population: focus on validity and reliability of the Italian translation of the Hearing Handicap Inventory. 2007;27:18691.

3. Saccone PA, Steiger JR. Hearing Handicap Among Adult Residents of an Urban Homeless Shelter. Journal of Health Care for the Poor and Undeserved. 2007;18:161-72.

4. Rakhmawati L, Ratna A, Wijana. Peluang kejadian ototoksisitas pada penggunaan kanamisin dalam pengobatan tuberkulosis resisten obat ganda selama satu bulan. MKB. 2015; 47(4):224-30.

5. Kementerian Kesehatan RI. Pedoman nasional pelayanan kedokteran tata laksana tuberkulosis. Jakarta: Pedoman Nasional 
Pelayanan Kedokteran ; 2013.

6. WHO. Global tuberculosis report. Geneva: WHO press; 2015.

7. Huth ME, Ricci AJ, Cheng AG. Mechanisms of aminoglycoside ototoxicity and targets of hair cell protection. International Journal of Otolaryngology. 2011;2011:1-11.

8. Yulianti, Mahdiani S. Gangguan pendengaran penderita Tuberkulosis Multidrug Resistant. ORLI. 2015;45(2):83-9.

9. Reviono, Kusnanto P, Eko V, Pakiding H, Nurwidiasih D.

Multidrug Resistant Tuberculosis (MDRTB): tinjauan epidemiologi dan faktor risiko efek samping obat anti tuberkulosis. MKB. 2013;46(4):189-96.

10. Duggal P, Sarkar M. Audiologic monitoring of multi-drug resistant tuberculosis patients on aminoglycoside treatment with long term follow-up. BMC Ear Nose and Throat Disorder. 2007;7(5):1-7.
11. Schacht J, Talaska AE, Rybak LP. Cisplatin and aminoglycoside antibiotics: hearing loss and its prevention. NIH. 2013;295(11):183750.

12. Augustine AM, Chrysolyte SB, Thenmozhi K, Rupa V. Assessment of auditory and psychosocial handicap associated with unilateral hearing loss among indian atients. Indian J Otolaryngol Head Neck Surg. 2013;65(2):120-5.

13. Katijah K, Anniah M, Precious MN. Ototoxic effects of tuberculosis treatments: How aware are patients? African Journal of Pharmacy. 2009;3(8):391-9.

14. Sana MA, Raja Y. Quality of life among adult yemeni patients with hearing loss quality of life among adult yemeni patients with hearing loss. The Med J Cairo Univ. 2011;79(2):15761. 